\title{
TAVI v roce 2018: standard v léčbě aortální stenózy
}

\section{Michael Želízko \\ Klinika kardiologie, IKEM, Praha}

Aortální stenóza je nejčastější chlopenní vadou v dospělé populaci, prevalence je udávána od 3,4\% ve věku 75 let až po $18 \%$ ve věku 90 let a více. Významná a symptomatická aortální stenóza představuje jednoznačnou indikaci k intervenci, přičemž nemocnému je možno nabídnout klasickou kardiochirurgickou operaci (s náhradou chlopně mechanickou nebo biologickou protézou - AVR) nebo transkatetrovou implantaci aortální chlopně (TAVI).

Chirurgická náhrada chlopně byla považována za standard s nízkou mortalitou a nízkou incidencí komplikací (a-v blokáda, paravalvulární regurgitace - $P V L$, nepoměr pacient-protéza PPM) a dosud jde o jediný způsob, jak implantovat mechanické protézy (podle guidelines ESC vždy u nemocných ve věku <60 let). U starších nemocných je preferována implantace bioprotézy z důvodu eliminace antikoagulace, přičemž při použití ověřených typů bioprotéz (osvědčené typy stentů, modifikace biologické tkáně chlopní) je udávaná životnost až $70 \%$ za 15 let.

TAVI byla poprvé provedena $v$ roce 2002 s pưvodní myšlenkou méně invazivního výkonu při eliminaci chirurgického traumatu, srdeční zástavy a kardiopulmonálního bypassu. První randomizované studie $(1,2)$ prokázaly, že TAVI je jedinou možností pro inoperabilní nemocné (studie PARTNER 1B). Řada randomizovaných studií $(3,4)$ poté prokázala, že TAVI je plně srovnatelná s AVR u nemocných s vysokým rizikem (STS skóre nad 8\%) a v prípadě transfemorálního prístupu je výhodnější nežli AVR (PARTNER 1A, CoreValve High-Risk). Nové studie $(5,6)$ prokázaly lepší efekt TAVI proti AVR u nemocných se středním rizikem (PARTNER 2A a SURTAVI Trial) z hlediska symptomů a časné rehabilitace, u transfemorálních výkonů byla nejnižší mortalita. Obdobně příznivé výsledky TAVI byly i u nemocných s nízkým rizikem (NOTION trial - 7). TAVI má ve srovnání s AVR méně krvácivých komplikací, ale vyšší výskyt PVL a převodních poruch s implantací kardiostimulátoru.

TAVI tak významně rozširíila svá indikační kritéria a dnes je preferovanou metodou v léčbě symptomatické významné aortální stenózy u nemocných se středním či vysokým rizikem AVR (STS skóre $\geq 4 \%$ ), u nemocných $\geq 75$ let věku, u nemocných po předchozím kardiochirurgickém výkonu či u nemocných s problematickou rehabilitací po AVR. Z anatomických situací je TAVI preferována u nemocných s porcelánovou aortou, prítomností průchodných koronárních bypassů, po radiaci hrudníku, prí deformitách či skolióze, a to zejména při předpokladu transfemorálního prístupu. Naopak AVRje preferována u mladších nemocných (<75 let), s nízkým operačním rizikem (STS skóre <4\%) a u nemocných vyžadující kombinovaný výkon společně s AVR (významná mitrální/trikuspidální vada vyžadující chirurgickou korekci, významná ICHS řešitelná pouze $C A B G$, dilatace/aneuryzma ascendentní aorty, septální hypertrofie vyžadující myektomii), a dále ve specifických anatomických situacích (rozměry aortálního anulu mimo možnosti TAVI, nízké odstupy koronárních tepen u malých anulů, nevhodná morfologie kořene aorty, problematická morfologie chlopně - unikuspidní chlopeň, bikuspidní chlopeň (8) s výraznou asymetrií sinů či těžce asymetrická distribuce kalcifikací chlopně/LVOT). Specifickou indikaci představují nemocní s degenerací bioprotézy (9), kdy implantace (nové) chlopně do (dege- nerované) chlopně (valve-in-valve) představuje nižší riziko nežli reoperace. Takto Ize implantovat novou chlopeň do degenerované aortální či pulmonální (zpravidla u vrozených vad při dysfunkci konduitu RVOT) chlopně, transapikálně či transseptálně do pozice mitrální (valve-in-valve, valve-in-ring) či vzácně trikuspidální.

TAVI se $v$ průběhu posledních deseti let významně zlepšila i po technologické stránce: došlo ke zmenšení průměru instrumentária (systémy je tak možno zavést femorální cestou při minimálním průměru tepny od 5,5 mm), samoexpandabilní systémy získaly v nové generaci možnost opakované repozice během implantace, chlopně mají speciální úpravy pro snížení rizika paravalvulárních leaků, existují dedikované zaváděcí systémy pro stále méně časté nefemorální prístupy (transapikální či transaortální implantace).

Společně s expanzí indikací a rozvojem instrumentária vyvstala potřeba definovat optimální podmínky pro diagnostiku a léčbu chlopenních vad. Byla definována tzv. „heart-valve" centra, která nabízí možnosti chirurgické i intervenční léčby včetně záchovných operací či kombinovaných výkonů. Tato centra by měla zajistit celý diagnostický postup i vlastní intervenci, pro což jsou vybavena moderními zobrazovacími technikami v nejvyšší kvalitě včetně TEE, 3D, zátěžové a perioperační echokardiografie, CT s dedikovaným software pro rekonstrukce, MR, moderními katetrizační sály s hemodynamickým hodnocením. Intervenční kardiologie musí mít velké zkušenosti i se strukturálními intervencemi. „Heart-valve" centra musí spolupracovat s referujícími nemocnicemi a tvořit tak sít, kde spolupracují lékaři primární péče s multidisciplinárním 
"heart-týmem", který tvoří kardiologové, intervenční kardiologové, kardiochirurgové, anesteziologové a další odbornosti tak, aby diagnostický a intervenční postup byl individuálně zvážen u každého konkrétního nemocného (nejen TAVI resp. AVR, ale i další intervenční kardiologické či kardiochirurgické indikace).

V letošním roce tomu bude deset let od první provedené transkatetrové implantace

\section{LITERATURA}

1. Leon MB, Smith CR, Mack M, et al. Transcatheter aortic-valve implantation for aortic stenosis in patients who cannot undergo surgery. N Engl J Med. 2010; 363(17): 1597-1607. 2. Kapadia SR, Leon MB, Makkar RR, et al. 5-year outcomes of transcatheter aortic valve replacement compared with standard treatment for patients with inoperable aortic stenosis (PARTNER 1): a randomised controlled trial. Lancet 2015; 385(9986): 2485-491.

3. Smith CR, Leon MB, Mack MJ, et al. Transcatheter versus surgical aortic-valve replacement in high-risk patients. N Engl J Med. 2011; 364(23): 2187-2198.

4. Reardon MJ, Adams DH, Kleiman NS, et al. 2-year outcomes in patients undergoing surgical or self-expanding tran- aortální chlopně v České republice (8. 12. 2008, IKEM - 10). Po dlouhém období velkých restrikcí, kdy metoda TAVI byla vyhrazena prakticky pouze inoperabilním nemocným za omezujících podmínek, se podařilo metodu TAVI postupně rozširirit na všechna komplexní kardiocentra a postupně uvést indikační kritéria do souladu s odbornými doporučeními, kdy rozhodnutí o provedení TAVI či AVR je dáno in-

scatheter aortic valve replacement. J Am Coll Cardiol. 2015; 66(2): 113-121.

5. Leon MB, Smith CR, Mack MJ, et al. Transcatheter or Surgical Aortic-Valve Replacement in Intermediate-Risk Patients. N Engl J Med. 2016; 374(17): 1609-1620.

6. Reardon MJ, Van Mieghem NM, Popma JJ, et al. Surgical or transcatheter aortic-Valve replacement in intermediate risk-patients. N Engl J Med. 2017; 376: 1321-1331.

7. Thyregod HG, Steinbrüchel DA, Ihlemann N, et al. Transcatheter versus surgical aortic valve replacement in patients with severe aortic valve stenosis: 1-year results from the all-comers NOTION randomized clinical trial. J Am Coll Cardiol. 2015; 65(20): 2184-2194. dividuálně, ale výhradně rozhodnutím „heart-týmu“. Je naším práním, aby plátci zdravotní péče tato rozhodnutí akceptovali a umožnili tak, abychom po deseti letech omezení mohli TAVI provést u každého nemocného, který tento výkon potřebuje, v souladu s aktuálními doporučeními Evropské kardiologické společnosti (11) a České asociace intervenční kardiologie.

8. Perlman GY, Blanke P, Webb JG. Transcatheter aortic valve implantation in bicuspid aortic valve stenosis. Eurointervention 2016; 12: Y42-Y45.

9. Mylotte $D$, et al. Transcatheter heart valve implantation for failing surgical bioprostheses: technical considerations and evidence for valve-in-valve procedures. Heart. 2013; 99(13): 960-967.

10. Zelizko M, Janek B, Netuka I, et al. Perkutanní implantace aortální chlopně u nemocné s těsnou aortální stenózou. Interv Akut Kardiol 2009; 8(1): 43-46.

11. Baumgartner H, Falk V, Bax JJ, et al. 2017 ESC/EACTS Guidelines for the management of valvular heart disease. Eur Heart J. 2017; 38(36): 2739-2791. 